DOI: $\underline{\text { https://doi.org/10.24297/ijrem.v11i.8595 }}$

\title{
Strategies of Developing Pre-University Education in Egypt In the Light of The Experiences of Some Foreign Countries.
}

\author{
Amal Saudi Abdel Zaher Sayed \\ Ph. D. Researcher, Philosophy of Education (Foundations of Education) \\ A.saudi@mhiet.edu.eg
}

\begin{abstract}
It has become satisfactorily convincing that the reformation and development of Egyptian education are inevitable. Education, in Egypt, has become one of the most rudimentary causes as it is the real and only beginning for any type of progress in all walks of life. Advanced countries, as has been affirmed by contemporary history, have started their progress from the gate of education. These countries always give education all the priorities in their policies, programs and strategies.

Efforts to reform and develop education in Egypt took various forms: Holding conferences, meetings, issuing documents and inventing strategies, etc. However, there are still many defects and gaps that need to be filled. These shortcomings actually impede the process of the reformation and development of education. Therefore, it has become an obligation to reconsider the policies and strategies of that system as an inevitable step to develop and promote it. To achieve the objectives of promoting the educational system in Egypt by creating a competent graduate, the study sought the experiences of some foreign advanced countries.

The descriptive approach has been used in this study to treat the data on a critical and analytical basis. The researcher has reached a number of important conclusions and lessons. Experiences of the advanced countries in the field of education clearly indicate that: 1-The minister of education should not be the only person to demarcate the educational policy; 2- education should be given a comprehensive outlook; 3- human and financial potentials should be always available; 4- societal participation and contribution by the experts, teachers, consultants, and administrative offices should be guaranteed. Accordingly, the educational policy will surely be entrusted to those who are able to carry it out successfully and in an integrated way. This ensures the reformation and development of the educational system in Egypt.
\end{abstract}

Keywords: Strategy, Education, Development, Strategic Plan, Pre-University Education.

\section{Summary of the Study}

\section{Introduction}

All developed and developing countries view with great interest the issue of developing and upgrading education because it plays a crucial role in the constructive process of manpower who can work efficiently to maintain and develop a life of their society in a way that achieves its security and social stability. Therefore, all countries of the world, among their major priorities, have earnestly sought to review and modify their educational systems thoroughly and radically: The goal has been to prepare their citizens and societies for the twenty-first century ${ }^{(10)}$ Therefore, education occupies the forefront in the official speech and daily interaction in many countries of the world at present and the cause of its development and modernization is not an issue that concerns itself only with the ministry of education. Rather, the presidents of some developed countries were keen to place this issue at the top of their agendas, and the emergence of the famous report: "A Nation at Risk" in the United States in 1983 was an indication of this awakening in the field ${ }^{(11)}$. 
Despite the prestigious global standing of the United States, there was a growing sense that the American educational system was suffering a deficiency in its role in preparing the American citizen and society in general for the twenty-first century. This sense had prompted the American President "Ronald Reagan" to form a presidential committee at the highest level to review this system and propose strategies and policies to develop it, so that the United States should not lose its privileged position.

Similar initiatives in Japan, India, and other countries have coincided with or followed directly the American imitative. Egypt was not isolated from the events and changes taking place in the world. On the contrary, Egypt has been in the center of events because of its historical and geographical location. The President of Egypt has stressed more than once that education is Egypt's largest national project, and that it is a front of the national security ${ }^{(7)}$.

\section{The Problem of the Study}

There are many deficiencies and shortcomings in the educational system in Egypt that still do exist despite all the efforts made to reform and develop this system. These deficiencies impede the process of reformation and development and affect negatively the educational system. This situation obliges the people in charge to start reviewing, bridging the gaps and reforming pre-university education in Egypt.

Many studies and official reports have revealed the shortcomings of the educational system, and highlighted many obstacles that prevent the achievement of the desired educational quality. Most studies have agreed that public education in Egypt actually suffers a great deal of waste at the quantitative and qualitative levels, and is still suffering from traditional and stereotyped formality and decentralization in decision-making and its implementation. It also depends on the teaching styles of trial and error, inculcation, and memorization, and there exists a gap between the stated objectives and their actual realities on the ground, especially at the operational and procedural levels. ${ }^{(8)}$

The Strategic Economic Trends Report (2008) indicates that there are problems that plague education in Egypt, such as the high density of classes, the dropout from school, and the poor state of school buildings. The plan of 2014, additionally, launched that education still suffers from several problems: A number of schools are too old to be used any more, activity halls and playgrounds almost disappear, many teachers are not educationally qualified, and a number of government schools (around $85 \%$ ) are not equipped with technology, etc. The layman can easily notice that there are insurmountable problems that might cause education in Egypt to stumble and not to compete either at the local or global level. ${ }^{(13)}$

Therefore, it has become inevitable, more than ever, to seek help from foreign advanced countries by examining their experiences in the field of educational development, in a hope to overcome the problems of education. If these problems are remedied, then there is a hope for reforming and developing this system.

\section{Study Questions:}

1- What are the strategies and plans for developing and reforming pre-university education in Egypt? and what are the obstacles that prevented these strategies to succeed in the reformation of education especially from the year 1980 up till now?

2- What is the experience of the United States in developing pre-university education?

3- What is the experience of Japan in developing pre-university education?

4- What is the possibility of benefiting from foreign experiences in setting strategies and plans for developing pre-university education in Egypt?

\section{Objectives of the study:}

The main objective of the current study is to display the strategies and plans set by some foreign countries to develop their pre-university education. This display might be significant in making use of such experiences in 
reforming and developing pre-university education in Egypt either through the transfer or borrowing from such experiences.

\section{The Approach of the Study:}

The descriptive approach that goes in line with the nature of the study has been used.

\section{The Significance of the Study:}

The present study tackles the serious cause of developing and reforming education. Findings of the study are of great concern to a multiplicity of groups that may benefit from these results, namely

- Educational policy planners who are entrusted with the issue of developing and reforming pre-university education;

- Ministry of Education whose officials may seize the opportunity to identify the problems and obstacles that lead to the failure of current educational strategies in Egypt;

- Research centers, the various administrations, and schools, etc., can make use of the results of the study in the reformation and development of pre-university education in Egypt and promote its quality level.

\section{Terminology of study}

The present study specifically addresses the following terms:

\section{- Strategy of Education}

It is defined as the set of principles and rules that guide the planner or decision-maker to achieve the goals of the process of change; it is a set of ideas and principles that address the educational field in a comprehensive and integrated manner including major and detailed goals derived from these principles and methods of their implementation to achieve sustainable development. ${ }^{(14)}$

\section{- Development of Education}

"Ahmed Hejji" states that modernization and development of education are only intended attempts to improve and promote the educational system and to address and remedy its problems on scientific grounds so that education becomes our tool and means to be up to the challenges that surround us. ${ }^{(6)}$ Modernization, however, is not a transfer from foreign mediums because what is transferred or extracted from these mediums will not be in line with the new mediums that may have totally different environment. ${ }^{(1)}$

\section{Procedures of the Study}

The current study includes three axes briefly stated as follows:

- The first axis deals with strategies for developing pre-university education in Egypt.

- The second axis tackles the most important strategies and plans for the development and reformation of pre-university education in some foreign countries.

- The third axis is a vision of the possibility of benefiting from foreign strategies and plans in developing a strategy for reforming pre-university education in Egypt. 


\section{The First Axis}

The following is a brief display of the strategies, plans, and documents issued to develop and modernize education in Egypt:

The period from 1980 up to the present has witnessed:-the issuance of some documents and papers for the development of pre-university education - the establishment of some specialized centers, the declaration of the document of the development and modernization of education in Egypt, its policies, plans and programs of achievement in the year 1980 (issued during the era of Mustafa Kamal Helmy) - The Educational Policy Document in Egypt July, 1985 (issued during the era of Abdel Salam Abdel Ghaffar) emphasized that education in Egypt had to achieve three types of general strategic goals as follows:

- Humanitarian goals which would achieve the humanity of the individual.

- $\quad$ Social goals which would help to stabilize society with its systems and institutions.

- $\quad$ Economic goals which enable the community to have professional manpower. (3)

Then there were two Educational Development Strategies in Egypt in the years $1987^{(19)}$ and $1989^{(4)}$ (issued during the era of Ahmad Fathi Sorour). - Another Education Strategy ${ }^{(15)}$, issued in the era of Hussein Kamel Bahauddin, came in July 1992 under the title "Mubarak and Education": A Look at the Future", and it has several main axes, the most important of which are:

- $\quad$ Education is a national security issue for Egypt.

- $\quad$ Education is an investment.

- $\quad$ The Egyptian family should not bear additional burdens, whether financial or psychological.

- Equal educational opportunities are for all Egyptians.

- $\quad$ Public opinion and legal channels should be involved in the implementation of the new educational policy.

Other strategies followed, such as the National Strategic Plan for Reforming Pre-University Education in Egypt during the years from 2007-2012(9) and the pre-University Education Strategic Plan from2014-2030 ${ }^{(12)}$ bearing the slogan "Together we can provide a good education for every child." However, all these strategies, plans and documents were marred by a number of some shortcomings.

It has been noted and concluded that there was always instability of the educational policy due to its correlation with the change of the Minister of Education, so the change in the educational policy became linked with the person of the Minister and not with the national goals that education seeks to achieve. Therefore, the reforms were not destined to succeed and continue.

Again, Successive educational policies could not benefit from setting a unified vision for education goals, or agreeing on the priorities for achieving these goals; it was even more serious; each educational policy could not achieve the goals that it set for itself, and the following policy did not attempt to complete it and build on it, and it was found that it used to begin from scratch. To add insult to injury, Egypt suffered a political instability starting from 2011-2013, and this instability had its impact on the Egyptian educational system, in terms of the constant change of education ministers and leaders, and therefore a change in reform plans and strategies. No plan or strategy has been destined to be completed and to bear fruit. In general, there was no holistic view of the educational system with regard to the planning for the development and reformation of education as there was always the absence of an integrated and comprehensive long-term strategic plan for ten or twenty years to develop and update all the components of the educational system for pre-university education in Egypt. All 
these conclusions have, unwillingly, motivated the researcher to look for alternatives from abroad hop ing that these alternatives may have the potential to reform and develop the pre-university education in Egypt. So, the study goes instantly to the second axis.

\section{The Second Axis: Some Foreign Experiences in Developing Education:}

The following is a presentation of the most important foreign strategies and plans for the development of education:

\section{(1) American Model}

In the era of US President Ronald Reagan, the famous report "A Nation at Risk" was issued in (1983) as a warning of the inability of the American education system to prepare citizens for the twenty-first century, as this report pointed to weaknesses in American education, both with regard to its effectiveness in producing well-aware citizens and the report emphasized the increase of interest in practical sciences such as mathematics, biology, physics, chemistry, computer technology, and English. The Strategy for Education in 1991 and The America's Document ${ }^{(5)}$ in 2000 came as a practical response to the previous report, eight years after its issuance. The document charted the way for long-term solutions, and emphasized the role of education in the formation of the state.

\section{Defining the Vision of Educational Reform in America}

In this step, the strategic plans for educational reform since the beginning of the twenty-first century are displayed:

\section{The Education Reform Strategic Plan (2002-2007):}

The plan starting from 2002 included a vision that focused on equality in educational opportunities while encouraging distinction. The plan also included a set of strategic goals that had to do with-the academic achievement of students;-an increase in the interest for science, mathematics, as well as languages; -an emphasis on security and safety at schools paying much attention that they were free from drugs of all kinds, and finally -an interest in increasing opportunities for enrollment in higher education. (2)

\section{1- The Education Reform Strategic Plan (2007-2012):}

The plan starting from 2007 focused on ensuring equal access to education and encouraging distinction in education all over the country. It also included a message that promoted academic achievement to reach global competition. The plan also addressed several strategic goals focusing on the interest in teaching mathematics science, reading, and languages to obtain advanced positions in this respect. ${ }^{(17)}$

\section{2- The Education Reform Strategic Plan (2012-2014):}

The plan of (2012) included a vision that focused also on enhancing students' academic achievement and the preparation for global competition by promoting educational excellence and ensuring equal access to education. The plan provided all measures to define the performance level of education in all the states based on pre-set criteria. It also addressed several goals pertaining to each specific educational stage to make sure that standards of quality had been achieved at each stage with focus on the criteria of accountability, equality, the clean climate at school, good stance for the teachers, and the implementation of justice. ${ }^{(16)}$

It is clear from the above that the vision of 2002 during the era of President Bush focused on ensuring equality in educational opportunities, while encouraging distinction in education. As for the vision of 2007, it added another dimension, which was the preparation for global competition while preserving previous visions. The 2014 vision which began during the "Obama" era, confirmed the preceding visions, but rather combined them 
into one comprehensive vision by focusing on achievement and preparing for competition and excellence, with equal opportunities and with attention paid to the economic aspect, considering education to be the engine of the economic future of the United States. ${ }^{(18)}$

\section{(2) The Japanese Model}

Educational reform began in Japan in the 1980s during the era of the Prime Minister Nakasone. In 1987, a toplevel conference formed from educational experts was held in Kyoto. The papers, speeches, and documents presented by the Japanese experts focused on the seriousness of the problems in the Japanese educational system and there was a demand for its radical reform.

In January 2001 the Ministry of Education developed a plan for educational reform for the twenty-first century, which was an established plan for developing a comprehensive vision for educational reform, with specific policy plans to address specific axes. The Japanese Ministry of Education summarized ideas and proposals in seven strategies, and called them the "Rainbow Plan" or the "Seven Priority Strategies." To achieve the goals of this plan, several measures were launched with what was called the "National Campaign for Education Reform" and the most important strategy for achieving this plan was how to make people realize the seriousness of the situation and the importance of education reform, and then allow them to understand the necessity of the Rainbow Plan.

\section{The Rainbow Plan for Education Reform in 2001 consisted of seven strategies as follows:}

\section{The first strategy: Improving Student Proficiency:}

The strategy ensured that the content of the material be made easy for students to understand and that each class contains twenty students only when teaching basic and additional high-level materials that are set for distinguished students, and prepare classes so as to facilitate the use of educational techniques.

The second strategy: encouraged the creation of Japanese youth able to communicate with others and to participate in community service and various activities, while introducing a system that encourages community service by determining community service hours before graduation.

The third strategy: concerned itself with improving the educational environment and making it fun and stressfree. This was done by enriching cultural and sports activities, and by encouraging school club activities.

The fourth strategy: focused on transforming schools into educational institutions that gained the trust of parents and society. This was achieved by implementing the academic accreditation system, and it included selfreview by schools, the introduction of a resident supervisor system that helped the school to improve education, and school councils were activated with the participation of parents.

The fifth strategy: was concerned with preparing teachers professionally through the introduction of a system of compensation, bonuses and promotions for distinguished teachers, and the introduction of a teacher forced vacation system in order to obtain experience in the field of the labor market in companies or factories.

The sixth strategy: focused on establishing universities at high levels by encouraging higher education and scientific research. The Seventh strategy was concerned with developing a philosophy appropriate for the new century while improving education services by revising the basic law of education and amending it to suit the new century.

From the above it is clear that education reform in Japan depends on clear-cut and specific successive strategies and plans without any break or a chasm, and the following plan completes the preceding one without contradicting or reducing the amount of its predecessors, but rather completes its policy with modernization in response to scientific developments and internal and external challenges surrounding the country, taking into 
account customs, traditions and popular demand. It is also noted that in every reform, Japan was doing many measures of what was called the National Campaign for Education Reform, and its goal was to raise awareness of people and seek their participation and suggestions. In the reform plan with the 17 general proposals issued during 2000, the goals and aspirations of Japan in the twenty-first century had been stated with the hope of confronting the challenges of this century. And in the "Japan Rising Again" the plan of 2004 included five specific proposals to reform education, amend the Basic Law on Education, "the law that forms the basis of all laws related to education, improve academic ability by implementing country surveys, improve the quality of teachers through the establishment of higher vocational schools, and renew the teacher's qualification system from the perspective of the school's board of directors.

Finally came the basic plan for the advancement of education from 2008-2018. This plan was mainly concerned with the current state of education in Japan and the challenges it faces, the educational message, as well as the educational vision that should be pursued over the next ten years, including the goals and policies to be implemented and the basic requirements for the implementation of the plan in a comprehensive and systematic way.

Through a presentation of the latest plans for educational reform in Japan in the twenty-first century, it is noted that they are all convergent in their time frame; they are interrelated and sequential; they are set on the basis of prior justifications, and most of them meet external challenges and internal problems.

\section{The Third Axis:}

This axis is very crucial as it the main focus of the study and a prospective vision to benefit from foreign strategies and plans in developing a strategy for reforming pre-university education in Egypt

In light of the policies, strategies, and plans of some foreign countries, and the extent of their compatibility with the challenges of the new world order, it is possible to get some insight into these strategies to develop a strategic vision which may develop and reform education in Egypt, taking into account societal and cultural differences; therefore, the following points should be basically considered:

- The strategic plan should be presented to the public to revise, comment, and add their own inputs as is usual in all developed countries. The public should have their significant and pivotal role in the process of designing and updating any strategic plan.

- There should be a council of reforming and updating pre-university education as well as university education, so that reform plans for education are carried out in a comprehensive and integrated manner.

- A specific legislative framework should be established to approve of a long-term strategic plan for educational reform regardless of the change in educational leadership.

- There is always the necessity to activate community participation, and open effective communication channels between the school, parents, and members of the local community to exchange information, opinion, and services.

- There must be great care in the institutions for preparing the teacher academically and educationally because it is considered one of the priorities for the success of the educational process.

- The process of educational reform and development requires qualified and adequate financial and human potential as well as sufficient and long-term time, as reform and development is an ongoing and long-term process.

- Visions of plans and strategies were too general and loose, and did not touch the issue of preparing education for either local or global competition. These strategies did not also deal with issues of academic distinction on a scientific basis.

- The plans did not pay any attention to the upgrading of technical education and the teachers who teach to technical education students. Strategies should rule out any individual role in setting policies, strategies, and plans, especially the minister's role as the minister, regardless of his competence and capability, only works according to prior policies. So, there should be always the link between education policy and the state's general policy, since most educational policies and laws were related to the person of the minister 
and not to an institution to conclude, it has become a must to reform pre-university education in Egypt so as to produce a graduate who is up to the current era with all its challenges and more importantly a graduate who competes with his/her counterparts in the world, and contributes to the progress of his/her country.

\section{References:}

1. Ahmad Fathi Sorour: A Strategy for the Development of Education in Egypt, Cairo, the Central Agency for University and School Books and Teaching Aids, 1987, pp. 131-138.

2. Ahmad Fathi Sorour: Developing Education in Egypt - Its Policy, Strategy and Implementation Plan (Preuniversity Education), Cairo, Ministry of Education, 1989, pp. 13-25.

3. Ahmad Ismail Haji: Educational Administration and School Administration, Cairo, Dar Al-Fikr Al-Arabi, 1998 , p. 70.

4. Ahmad Ismail Hajji: Educational Administration and School Administration, Cairo, Dar Al-Fikr Al-Arabi, 1998 , p. 58.

5. Arab Republic of Egypt, Ministry of Education: The Strategic Plan for Education in Egypt (2007/2012) Towards a Qualitative Shift in Education, Ministry of Education, Cairo, 2007.

6. Arab Republic of Egypt: The Ministry of Education: The Strategic Plan for Pre-University Education in Egypt (2030/2014), Education the National Project for Egypt - Together we can provide a good education for every child, Ministry of Education, Cairo, 2014.

7. Arabic Organization for Culture and Science, Strategy for Developing Arabic Education (Updated Strategy), Tunisia (2006), P.20.

8. Dia Al-Din Zaher: Network planning for educational programs and projects, studies in education, first edition, Ibn Khaldoun Center for Development Studies, Cairo, 1992.

9. Dia Al-Din Zaher: Network planning for educational programs and projects, studies in education, first edition, Ibn Khaldoun Center for Development Studies, Cairo, 1992. P. 10-11.

10. Goverment of Japan, Ministry of Education, Culture, Sports, Science, and (Next) Basic Plan for the Promotion of Education, July 1, 2008. www.mext.go.ip/english/lawand.plan/1303463.htm.

11. Hamed Ammar, et. al. Globalization, first edition, Cairo, Printing and Publishing house 1999, p. 68.

12. Lamar Alexander; America 2001: An Education Strategy Sourcebook, Department of Education Washington, D.C., 8 April, 1991, pp. 52-53 Nadia Youssef Kamal: Modern Trends in Educational Policy Making, The Future of Arab Education, Volume Seven, No. 20, January, 2001, p. 187.

13. Ministry of Education, Developing and Modernizing Education in Egypt: Policy, Plan and Programs, July (1983) pp.27-39.

14. Ministry of Education, Mubarak, and Education: An Outlook into the Future, Cairo (1992), pp. 13-23.

15. Muhammad Ibrahim Atwa Mujahid: Professional accreditation for the teacher: an introduction to achieving quality in education, Scientific Journal, p.48, College of Education, Mansoura University, 2002, pp. 317-352.

16. The Nation Commission on Excellence in Education at Risk; the Imperative for Educational Reform to the and Secretary of Education, United States Department of Education, Washington, D.C., April 26, 1983. 
17. U. S. Department of Education Strategic Plan for Fiscal Years (2007-2012), Department of Education Washington, D.C., May, 2007, p. 6.

18. U. S.: Department of Education Strategic Plan, (2002-2007) Washington, D.C., March, 2002.

19. U. S.: Department of Education Strategic Plan, For Fiscal Years (2011-2014), USA, 2011, p. 6. 